\title{
Study of College Students' Motivation to Join the Party under the New Situation
}

\author{
Yu He \\ Sichuan Agricultural University, Chengdu, Sichuan, 611130
}

Keywords: New Situation; College Students; Join The Party Motive; Ideals and Beliefs

\begin{abstract}
Under the background of current social and economic transition and political change, the motivations of contemporary college students' participation in the party are diversified and complicated, and the motives of the minority students are different. Based on the present situation of college students 'motivation to join the party, this paper puts forward the method of correcting the motivation of college students in China, hoping to make a certain contribution to college students' motivation to join the party after "90".
\end{abstract}

\section{Introduction}

China's higher education should always adhere to the socialist core values as a guide, the transmission of Chinese culture, cultivate more pillars of talent. Colleges and universities should always strengthen the education and education of college students' political beliefs, because it is related to the purity and advanced nature of the student party members, the relationship between the party's ability to govern, the future fate of the country and the smooth progress of the socialist modernization drive. In recent years, with the expansion of colleges and universities, college students to join the party's desire and proportion is also increasing, college students party members continue to grow. In the college student party members, most college students can be self-discipline, in their daily lives to play a pioneer model to take the lead role. But there are still a small number of student members self-demanding is not strict, the role of consciousness is weak, not only did not play a vanguard role, but also a violation of discipline and other acts, seriously affected the image of student members. As the main force and builder of the socialist cause, the political thought and the motive of joining the party not only affect its own development, but also directly related to the future fate of the party and the state, which is related to the socialist modernization construction.

\section{The current status of college students to join the party}

This kind of student has a solid theoretical knowledge, profound understanding of the party, deep feelings, strong sense of collectivity and social responsibility, with a firm political belief and a communist belief as his own code of conduct and lifelong goal. They believe that the party is an advanced organization and voluntarily join the party, in the ideological and theoretical understanding of the party more profound, I believe the Communist Party, firmly believe that only socialism can develop China, to join the party as their political pursuit, determined to keep up with the Chinese Communist Party , Study hard, actively participate in social work, the party-led cause of socialism with Chinese characteristics full of confidence. This part of the students in the party organization through the further training and inspection, after joining the party to further strict demands on their own, students can play a vanguard role in the classmates, determined to carry out the cause of socialism with Chinese characteristics and communist cause of life.

This type of college students believe that before and after the party must go through the various tests of the party organization, help to exercise their own. After they join the party in the party organization's careful cultivation and education, in the ideological consciousness and personal ability can be improved rapidly, in order to make their own fast to grow up to become a good person, these students will choose to join the party, after joining the party they will actively participate 
Internal and external activities, and efficient completion of the tasks assigned by the party organization. But usually only concerned about the honor to bring them to the party, they often do not realize that joining the party is not only a belief, but also a responsibility, which led to a large extent only note

So that when personal interests conflict with the collective interests, they will choose personal interests, political stance is not firm, once the face of threats and temptations, it is easy to make mistakes. They will see the party as a way to improve themselves and prove their own value, but too much attention to self will lead to self-centered, which led to the party only to meet the individual's vanity and neglect the party's obligations and responsibilities, so this is An impure motive for joining the party.

This class of students do not have the exact political pursuit of the goal, for the party's understanding is not clear, just blindly follow the behavior of other students, do not want to lag behind others, driven by the psychologist to submit the application to join the party. They do not have a firm communist belief that the party's understanding is simply to stay on the surface, but they have a high plasticity.

This kind of college students' motivation to join the party has a strong utilitarian, they will join the party as the future development of the advantages of

Is an important indicator of future work, they want to join the party to bring them benefits. In the market economy conditions, there are indeed some positions for the party members of the "preferential treatment", at the same time, to join the party and their friends and relatives to win the honor, say "face", to be praised by others, etc. These reasons will make college students The motivation to join the party becomes utilitarian. This part of the students do not have a correct understanding of the party, the lack of a firm belief in the pursuit of the need for further education and guidance to them, so that they better understand the party, faster mature.

This type of student is affected by the family or teacher, passively submitted to the party application. Their own willingness to join the party is not strong, in the ideology and action are more passive, for the party's request and the relevant procedures were indifferent, apply for membership only to the family or the teacher has an account, in order to complete the task. Such students often lack the spirit of autonomy and internal initiative, the desire to join the party organization is not urgent, in the process of joining the party lack of perseverance and perseverance, not keen on public welfare activities and collective life.

\section{The current reasons for the diversity of college students to join the party}

We should be a comprehensive, objective and rational view of the status of contemporary college students to join the party: on the one hand the contemporary "90" after the college students to join the party motive of the diversification phenomenon is not accidental, but internal and external work together because of the results; on the other hand should be scientific analysis The reasons for its diversification, mainly summarized as the following factors:

Facing the complex and ever-changing domestic and foreign situation, the Chinese Communist Party to withstand the pressure of all sides, difficulties and comprehensive deepening reform. Reform and opening up to China has brought tremendous changes, especially for the implementation of the 18th National Congress on the comprehensive reform of the strategic plan, the Third Plenary Session of the 18th to deepen the reform to make new demands. However, under the influence of the comprehensive exchange and cooperation between China and the West, contemporary college students have begun to appear all kinds of psychological problems, showing that they can not develop their own development closely with the development of the party and the country. In particular, some college students have appeared in faith crisis. As the "90" after the growth of college students in the reform and opening up the era of peace, some students on the political beliefs on the performance of some indifference, not enough concern for the development of the party and the country, leaders and revolutionary pioneers have no hypocritical enthusiasm, the reality of some college students The lack of faith in the status quo is particularly worrying: such as the lofty ideals of the lack of, over and over; spiritual life empty, value-oriented deviation; 
loyalty of the distortion, lack of righteousness and so on. "90" after the students must have a scientific sense of faith and responsibility in order to build a prosperous and democratic democracy and harmony of the socialist modernization of the country to contribute their strength, will not live up to the expectations of the country and the nation.

In recent years, China's social organization, production and lifestyle have undergone tremendous changes, that is, our country is in a social structure of the transition period, human values affected by various factors, but also gradually change, showing Diversified trend, in the "90 after" college students hedonism, money worship and extreme individualism ubiquitous, abuse of power, abuse of power, corruption and minority party members and cadres there are some serious impact on the ideological positions, college students thinking belt To a certain negative impact, "90 after" college students "three view" has not yet fully established, self-control ability is poor, in front of these social phenomena, "90" often can not stand firm, the phenomenon of widespread belief crisis The

Now the major colleges and universities are in the implementation of enrollment, in the pursuit of connotation of the development of colleges and universities, the process of extension of the expansion of college students for the education there is a certain deviation. The main achievements are: (1) the number of college students to join the party and the number of party building workers in colleges and universities there is a huge difference in the number of workers on the program mostly concerned about the application for college students to the initial study, ignoring their After the re-education. (2) focus on the party's theoretical study, pay attention to policy and situation education, but still use indoctrination education. (3) Now the university is using a centralized education model, almost no depth of education and individual interaction, easy to student members to partial general. (4) the party building team is a bridge between students and school administrators, party members and members of the backbone of the party to help the party to deal with grass-roots management of things to play a great role. In order to stimulate the enthusiasm of the work of the party workers often interested in meeting the utilitarian needs of students, so slowly mislead the student's political value orientation. (The contrast between moral practice and moral education, the ideal education that students receive at school is impacted by social reality, which makes the students have a great misinterpretation of the motives for joining the party, resulting in a series of adverse reactions.

Family is the first classroom of student growth, parents are the first teacher of the child, family education on the formation of the child's ideological personality has a fundamental role. Many of the contemporary college students are the only child, parents look forward to Jackie Chan, often pay more attention to the child's material life protection, not pay attention to their children's ideological and political education and socialist core values. Some college students because of elders excessive spoil, resulting in self-centered individualistic character characteristics, quick success, selfishness. Some parents elders childhood education children grow up to join the party, into the party has a face, political capital, the future can find a good job, get good development. Under the influence of this quick success, some college students to join the party began with a significant utilitarian color.

"90" after the college students as the main body of education in contemporary colleges and universities, is from the school to the social transition period, they lack the social experience and political experience, the lack of objective, dialectical, comprehensive analysis of the ability. "90" after the growth of college students in the Internet era, they contact more information, learn new knowledge and new skills, initiative, innovation and creativity to create strong, broad vision, distinctive personality, ideological emancipation. As the understanding of the party is basically learned by books and teachers to teach, they have less understanding of the history of the party, the study of Marxist theory is not deep enough, China's national conditions, party attention less, and thus may exist in the value orientation Part of the students to promote individualism, self-centered, the pursuit of unconstrained freedom of thought, and to some students caused a bad influence, completely deviated from the lofty ideals and the pursuit of communism. Under the new situation, in the face of various complex contradictions in the period of social transformation and the ideological and cultural infiltration of the Western hostile forces, some students have deviated and misunderstand the Party's understanding, resulting in their adverse effects on world outlook, outlook 
on life and values.

\section{Correct way to college students to join the party}

Purify the network environment, compete for network positions. With the popularization of the Internet, the network has brought new challenges and opportunities to the development of party members in colleges and universities. Social network platform should use modern information technology to build red website to hone students' motivation to join the party, the network of college students ideological and political education, grasp the correct guidance of public opinion, and resolutely resist the negative and harmful information on college students erosion. The use of QQ, microblogging, paste it and other new ways to strengthen the basic knowledge of the party to guide the formation of the correct motivation for students to create a new platform. In addition, the promotion of correct, rational, active use of the network and microblogging, which will not only expand the field of ideological education, but also to make new ways closer to the "90" after the current study and life status of college students, play a better education guide role.

To increase the national labor model and outstanding communist advanced deeds of propaganda. The use of national model workers and outstanding members of the typical story of education students, and truly establish the positive image of party members and cadres in the hearts of students to eliminate the negative impact of individual corrupt elements, so that students really understand the cause of the Communist Party of China and communism, unknowingly correct Join the party motive, establish a firm communist faith.

Establish a typical, carry forward the deeds, play an example of the role of incentives to guide. Ideological and political counselors and other colleges and universities party workers, to work hard in the usual learning life, found that students in the excellent example, as far as possible around the typical characters and advanced deeds to the majority of students in learning and contrast to find their own deficiencies, improve themselves, To improve their own initiative and enthusiasm; when the cause of socialist construction in China emerged outstanding party members and their advanced deeds, you can use new media to promote, and by watching the video, seminars and other forms of students to its To carry out specialized study and discussion, the use of outstanding members of the typical deeds, influence, drive college students, so that students who join the party intention to establish a model and benchmark from the heart to find their own deficiencies, and thus correct the motivation of college students to join the party.

Should make full use of the political theory of colleges and universities, and further deepen the "90 after" the ideal of college students education. Through the political theory course, the young college students can further promote the ideals and beliefs and improve the political theory. At the same time, , To explore the teaching model extensively, to further enrich the teaching content of political theory courses in colleges and universities, to fully mobilize the enthusiasm of "college students to join the party after 90", and to convey the concept of the party to the broad masses of students through the pleasant and easy teaching mode so that the political theory Students accepted.

To strengthen the construction of teachers and morals, regulate the words and deeds of teachers. Educators should shoulder the important task of developing party members, not spread the mistakes and opinions of the policy and the party's line policy, but should improve their theoretical level, the ideological and political education in the professional, discipline teaching, Play the role of teachers as a teacher. Colleges and universities should establish a strong political ideology, solid theoretical quality, party spirit and firm party organizations and party cadres to improve their influence in the development of the object to ensure the quality of the development of party members, standing on a strategic height to understand the strengthening of education and guidance, Correctly join the party motive, the good "entry".

To strengthen the practice of college students exercise. The correct motivation for college students to join the party is not inherently generated, but in a variety of practical activities in the gradual establishment. Social practice has changed the shortcomings of traditional theoretical education, so that college students out of the classroom, by participating in various forms of social practice activities to enhance the appeal and attractiveness of the party motive education. Marxist 
epistemology tells us that human correct cognition, through practice - cognition - and then practice this continuous process of reciprocation can be obtained. This is because practice is the foundation, but also test the truth of the standard. Through real life to engage in practical activities to go, to deepen the students on the party, the further understanding of communism, strengthen the correct motivation to join the party. Therefore, the party organization should fully mobilize the enthusiasm of the students to join the students in the self-management work, campus cultural activities, volunteer activities, social practice and other activities to fully demonstrate their ability to exercise their comprehensive ability to play their students In the exemplary role, so that they continue to experience in practice with the experience of the party in the cause of the revival of the outstanding contribution to the cause, so as to deepen the understanding of the party to the party, and further correct their own motives.

\section{References}

[1] Sun Qiang. College students to join the party motive study "SA" method [J]. Jiangsu Higher Education, 20126 period.

[2] Lei Zujun. Give full play to the role of college workers in correcting college students' motivation to join the party [J]. Journal of Ideological Education, 2010, 9.

[3] Lu Jun, Yin Yujie. From the demand theory to explore the motives of college students to join the party [J]. People's Forum, 201332 period.

[4] Tang Bowu. Current college students to join the party motive investigation and analysis [J]. School Party building and ideological education (Higher Education Edition).

[5] Liu Zhiyuan, Li Zhonghua. Reflections on the current motivation of college students to join the party [J]. Contemporary Education Forum (Macro Education Research), 2007 (03). 